\title{
RISK ASSESSMENT OF RENEWABLE ENERGIES: GLOBAL EXPOSURE
}

\author{
G.S. CHEBOTAREVA \\ Academic Department of Energy and Industrial Enterprises Management Systems, Ural Federal \\ University, Russia.
}

\begin{abstract}
The current stage of renewable energy (RE) development poses new challenges to this sector. The existing mechanisms of state stimulation of Renewable energy system are gradually exhausting its capacity. This requires the development of new methods to support the industry, or giving them up altogether. This article presents the results of the theoretical analysis of the systemic features of RE risk assessment at each stage of a project's life cycle. A sectoral approach to the risk assessment of energy projects is proposed. It is based on the well-known logit-model that studies a set of external and internal indicators. Based on this model, a study of the dynamics of the risk indicators of RE projects on three basic stages was conducted. Calculations were made for RE projects implemented in different countries of the world, including China, USA, Canada, Japan, India and a number of European countries. Initially, all projects were divided into three main groups depending on the types of state support: concessional lending, subsidies or the lack thereof. Based on the results of the calculations, the overall and average dynamics of risk by group and by project stage allowed for assessing the global effectiveness of state measures to support the sector, as well as for drawing appropriate conclusions in the context of individual countries. The results of the study are of practical importance and will be used in developing a new approach to risk assessment, taking into account the specifics of the RE market, as well as in enhancing the concept of competition in the global energy market. Keywords: energy, investment project, logit-model, project'stages, renewable energy, renewable energy sources, risk, risks' distribution, state support.
\end{abstract}

\section{INTRODUCTION}

Renewable energy (RE) is an example of an 'unconventional' sector in terms of project risk assessment. In particular, it is important to highlight the following main features [1]-[4]: standard financial risks have a minimal impact on the effectiveness of RE projects and sector companies [1], [4]; the most significant risks in the activities of the sector companies and projects are risks caused by a set of political factors (legislative, financial and other types of dependence of investors, instability of state support, etc.) [4]; a lot of instruments of state support for RE projects cause heterogeneous risks of various levels of impact; political risks, including those related to state support for the sector, are typical of RE projects throughout the life cycle; a relatively short life cycle of RE projects (2-3 years on average) complicates the task of more detailed and strategic risk assessment of the sector projects; relatively recent development of the RE market prevents the accumulation of sufficient statistical information for the use of exclusively deterministic methods of risk assessment for projects; to improve a project's efficiency, risk assessment in RE should be connected to at least three main stages of the life cycle.

Together, the above features of risk assessment in RE projects and the current need for state support of this sector give rise to a complex and urgent task of conducting theoretical and applied research of efficiency and reasonability of state stimulation measures for RE projects in the context of the assessment of specific sector risks. This study examined RE projects implemented not only in the leading countries of the sector (China, US, EU countries), but also in other regions (India, Canada, Russia, etc.) [5]-[10].

The result of the study is the theoretical systematization of the main features of the evaluation of RE projects, including the various stage by stage steps, while taking into account the specific 
features of each one of them. This article presents a practical assessment of the effectiveness of state support measures for RE on the basis of the risk-oriented logit-model. The results of the calculations were used for comprehensive comparative assessment of the reasonability of two methods of state support and non-provision thereof. It includes the exclusion of RE projects that did not initially require any state support from a risk perspective. The obtained results are of practical importance and will be used in the development of a fundamentally new risk-based approach to the evaluation of RE projects at each stage. In the future, this will enable the development of the author's concept of competition in the global energy market [11].

\section{PECULIARITIES OF RISKS ASSESSMENT FOR RE PROJECTS}

The risk assessment of RE projects should be connected to the stages of the project life cycle. The short duration of RE projects requires that the study only evaluate three main stages of the project: pre-investment, investment and post-investment. In general, they are characterized by the following features:

1. Each stage has its specific features content-wise, which determine a specific approach to risk assessment.

2. The combination of risks at each stage can be strictly distinct, and each risk has its own individual level of influence and probability.

3. Risk assessment is stage-specific, depending on the period and related forecasts.

4. Stage-specific risks are studied over time. This study makes possible to assess how effective risk management programs are at each stage of the RE project.

The specific characteristics of risk assessment at each stage of RE projects are presented in Table 1.

Table 1: Peculiarities of risks assessment in renewable energy projects:

current status.

\begin{tabular}{|c|c|c|c|c|}
\hline \multirow[b]{2}{*}{ Stage } & \multirow[b]{2}{*}{$\begin{array}{c}\text { Short } \\
\text { characteristic }\end{array}$} & \multicolumn{3}{|c|}{ Features of risks assessment } \\
\hline & & $\begin{array}{c}\text { Initial } \\
\text { information for } \\
\text { assessment }\end{array}$ & $\begin{array}{l}\text { Methods for } \\
\text { risks } \\
\text { assessment }\end{array}$ & $\begin{array}{l}\text { Evaluation of } \\
\text { political risk }\end{array}$ \\
\hline 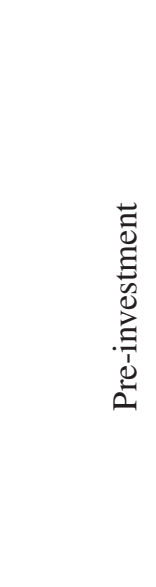 & $\begin{array}{l}\text { Project plan- } \\
\text { ning, organiza- } \\
\text { tion of financing }\end{array}$ & $\begin{array}{l}\text { Only forecast } \\
\text { information } \\
\text { on the project, } \\
\text { including risks, } \\
\text { and the market } \\
\text { state (data of } \\
\text { the business } \\
\text { plan); availabil- } \\
\text { ity of informa- } \\
\text { tion on the } \\
\text { implementation } \\
\text { of RE projects } \\
\text { with similar } \\
\text { characteristics }\end{array}$ & $\begin{array}{l}\text { Preferential } \\
\text { use of qualita- } \\
\text { tive (expert) } \\
\text { methods of risk } \\
\text { assessment }\end{array}$ & $\begin{array}{l}\text { High uncer- } \\
\text { tainty about the } \\
\text { possibility of } \\
\text { state support, } \\
\text { existence of as- } \\
\text { sociated risks }\end{array}$ \\
\hline
\end{tabular}




\begin{tabular}{|c|c|c|c|c|}
\hline 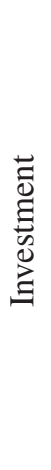 & $\begin{array}{l}\text { Construction } \\
\text { and commis- } \\
\text { sioning of the } \\
\text { RE facility }\end{array}$ & $\begin{array}{l}\text { Actual data on } \\
\text { the RES project, } \\
\text { the market state; } \\
\text { clarification of } \\
\text { the calculations } \\
\text { on the level of } \\
\text { risk before the } \\
\text { stage (project } \\
\text { reports, con- } \\
\text { tracts) }\end{array}$ & $\begin{array}{l}\text { The combina- } \\
\text { tion of qualita- } \\
\text { tive and quanti- } \\
\text { tative methods, } \\
\text { the priority of } \\
\text { mathematical } \\
\text { models in the } \\
\text { accumulation of } \\
\text { data on current } \\
\text { and similar RE } \\
\text { projects }\end{array}$ & $\begin{array}{l}\text { High probabili- } \\
\text { ty of instability/ } \\
\text { cancelation of } \\
\text { state support, } \\
\text { the existing of } \\
\text { associated risks }\end{array}$ \\
\hline 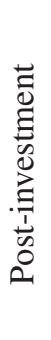 & $\begin{array}{l}\text { The operation } \\
\text { of the RE facil- } \\
\text { ity }\end{array}$ & $\begin{array}{l}\text { Accurate proj- } \\
\text { ect data before } \\
\text { commission- } \\
\text { ing of the RE } \\
\text { facility }\end{array}$ & $\begin{array}{l}\text { It is possible to } \\
\text { use only quan- } \\
\text { titative tools } \\
\text { with sufficient } \\
\text { information on } \\
\text { the implementa- } \\
\text { tion of the RE } \\
\text { project }\end{array}$ & $\begin{array}{l}\text { Reducing the } \\
\text { impact of po- } \\
\text { litical risks }\end{array}$ \\
\hline
\end{tabular}

The comparison of risk indicators for adjacent stages makes it possible to evaluate the efficiency of the risk forecasting and management system in RE project. The calculated risk at the pre-investment stage is a forecast one for the investment stage; at the investment stage is a potential one for the post-investment stage of the project.

Integration of the specified features in a single mathematical model will make it possible to estimate quantitatively an individual level of risk at each stage of the RE project. From the methodological perspective, the solution of this problem will be the basis for the quantitative assessment of the political risk, which has a significant importance for RE, and indicate the expediency of state support for the project at each stage.

\section{METHODOLOGICAL APPROACH TO RISK ASSESSMENT OF RE PROJECTS}

The study of the level of risk in renewable energy system (RES) projects is based on a globally recognized approach: assessment of the forecast logit-model in eqn (1) [12]-[14]:

$$
P D=\frac{1}{1+e^{Y}},
$$

where $P D$ is Probability of Default of RES project; $e=2,71,828$; indicator $Y$ is an integral indicator estimated by the proposed model.

The calculation of the probability of a default of projects is based on the model (2), taking into account the specific characteristics of the country's economy, local and international energy market [14]:

$$
\begin{gathered}
Y=-a_{0}-a_{1} \cdot K_{1}-a_{2} \cdot K_{2}-a_{3} \cdot K_{3}-a_{4} \cdot K_{4}-a_{5} \cdot K_{5}-a_{6} \cdot K_{6}-a_{7} \\
K_{7}-a_{8} \cdot K_{8}-a_{9} \cdot K_{9}-a_{10} \cdot K_{10}-a_{11} \cdot K_{11}
\end{gathered}
$$


where $a_{0}, a_{1}, \ldots, a_{11}$ are the indust-specific constants of significance of the coefficients for the fuel and energy sector.

The qualitative assessment of energy projects is provided by the dummy-variables $K_{1}, K_{2}$, $K_{7}$, namely: $K_{1}$ takes into account the factor of 'age' of the energy company, $K_{2}$ is the characteristics of the credit history of the energy company-project initiator, $K_{7}$ reflects the regional affiliation of the project. They take values according to the conditions (3):

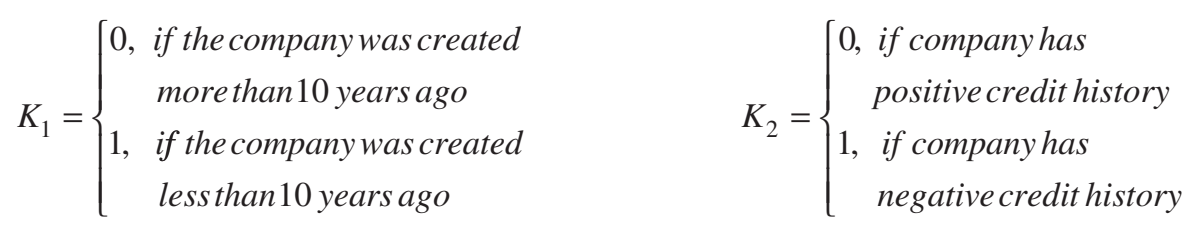

$$
K_{7}=\left\{\begin{array}{l}
0, \text { if company is located in the capital } \\
1, \text { if companyis not located in the capital }
\end{array}\right.
$$

The quantitative assessment of the risk level is based on the calculation of other exogenous and endogenous financial and economic indicators: $K_{3}$ is the current ratio of the project; $K_{4}$ the ratio of profit before tax and interest paid in the project for the period; $K_{6}$ the weighted average key interest rate of the Central Bank; $K_{8}$ the return on assets; $K_{9}$ the return on equity; $K_{10}$ the growth rate of the project equity capital and $K_{11}$ the growth rate of assets of the project for the period.

$$
K_{5}=\ln \left(\sum_{\beta=1}^{m} E C_{\beta}\right)
$$

where $K_{5}$ is the weighted average capital of the company; $E C_{\beta}$ the equity capital of the energy company for the $\beta$ period.

Taking into account the specific features of the fuel and energy sector, the distribution of industry-specific constants is presented in Table 2.

The proposed model assumes the following total values (5):

$$
\mathrm{PD}=\left\{\begin{array}{l}
{[0 ; 0.2)-\text { minimal risk of project }} \\
{[0.2 ; 0.4) \text { - low risk }} \\
{[0.4 ; 0.6) \text { - average risk }} \\
{[0.6 ; 0.8) \text { - high risk }} \\
{[0.8 ; 1] \quad \text { - maximum risk }}
\end{array} .\right.
$$

Table 2: Value of the constant coefficients of the model for the fuel and energy sector.

\begin{tabular}{lcccccc}
\hline Indicators & $a_{0}$ & $a_{1}$ & $a_{2}$ & $a_{3}$ & $a_{4}$ & $a_{5}$ \\
\hline Value & $3,07,371$ & 37,033 & 89,734 & $-86,711$ & $-70,110$ & $-16,427$ \\
Indicators & $a_{6}$ & $a_{7}$ & $a_{8}$ & $a_{9}$ & $a_{10}$ & $a_{11}$ \\
Value & -0.1399 & -0.6913 & $-50,894$ & $-1,53,882$ & 73,667 & $-2,20,294$ \\
\hline
\end{tabular}




\section{PRACTICAL ASSESSMENT OF RISKS IN RE PROJECTS}

An assessment of the risks distribution by stage was carried out for 28 selected RE projects in different countries. It includes countries such as China, USA (market leaders [5], [6]), a number of European countries, as well as India, Japan, Russia and others. The subjects of the study are projects that lie within the popular top-priority areas of RE development: solar, wind, hydro, geothermal and bioenergy.

All projects are divided into three groups according to the methods of direct state support: concessional lending (10 projects, $35.7 \%$ ), subsidies ( 7 projects, $25 \%$ ) and the absence of state support (11 projects, $39.3 \%$ ).

An important feature of RE projects is their relatively short life cycle (about 2 to 3 years). Therefore, within the framework of this study, it is assumed that the pre-investment stage lasts only the first 6 months, the post-investment stage for the last 6 months and the investment stage throughout the entire duration of the project.

\subsection{Distribution of risks in the case of concessional government lending of RE projects}

Table 3 shows the results of risk calculations for the RE projects that received concessional government lending.

The results indicate a rather low efficiency of the mechanism of concessional government lending: in three RE projects the risk level increased to the maximum value; in projects where the risk was at the maximum initially, the same dynamics remain [15], [16]. In a number of RE projects with a minimal risk at the pre-investment stage, this indicator also remains at the same level. However, such projects initially did not require state support as a tool of reducing risk.

To study the overall dynamics of the risk, the average value of the indicator at each of the three stages is calculated (last line of Table 3 and Fig. 1). Thus, the level of risk increases from stage to stage, reaching the average value to the post-investment stage.

\subsection{Distribution of risks in the case of subsidizing of RE projects}

Table 4 presents the distribution of the risk level by stages in the case of non-repayable subsidies for RE projects.

The study of the subsided RE projects did not reveal any dependencies on the stages. In this case, RE projects demonstrate a stable maximum or minimal risk value, an increase of risk to the maximum level or a decrease to the minimal to the post-investment stage. Therefore, there is not the sustainable positive influence of the mechanism of subsidies on the efficiency of RE projects [16], [17].

The mean value of risk for such projects varies insignificantly within 0.015 in the zone of average risk (last line of Table 4 and Fig. 1).

\subsection{Distribution of risks in the case of the absence of state support for RE projects}

The results of risk distribution in case of the absence of direct state support are presented in Table 5 .

Almost half of the described RE projects show a stable minimal risk level. Such projects initially do not require any government incentives. Less than a third of the reviewed projects are characterized by the maximum level of risk (in one case - an increase to the maximum value). The remaining RE projects are able to either reduce the level of risk, including to the minimum value, or remain within these limits. 
Table 3: Distribution of risks: government lending.

\begin{tabular}{|c|c|c|c|c|c|c|c|}
\hline $\begin{array}{l}\text { RES } \\
\text { types }\end{array}$ & Project & Initiator & Period & Stage & Duration & $\begin{array}{c}\text { Risk } \\
\text { (avg.) }\end{array}$ & $\begin{array}{c}\text { Risk } \\
\text { profile }\end{array}$ \\
\hline \multirow{18}{*}{$\begin{array}{l}\text { Solar } \\
\text { power }\end{array}$} & \multirow{3}{*}{$\begin{array}{l}\text { Solar genera- } \\
\text { tion facility in } \\
\text { the Mojave } \\
\text { desert, USA }\end{array}$} & \multirow{3}{*}{$\begin{array}{c}\text { Government of } \\
\text { USA, Abengoa } \\
\text { SA }\end{array}$} & \multirow[t]{3}{*}{$\begin{array}{c}2016- \\
2017\end{array}$} & $\begin{array}{l}\text { Pre-invest- } \\
\text { ment }\end{array}$ & 2016 & 0.478 & Average \\
\hline & & & & Investment & $\begin{array}{c}2016- \\
2017\end{array}$ & 0.739 & High \\
\hline & & & & $\begin{array}{c}\text { Post- } \\
\text { investment }\end{array}$ & $\begin{array}{l}\text { From } \\
2017\end{array}$ & 1 & Maximum \\
\hline & \multirow{3}{*}{$\begin{array}{l}\text { Solar gen- } \\
\text { eration facil- } \\
\text { ity in India } \\
(100 \mathrm{~mW})\end{array}$} & \multirow{3}{*}{$\begin{array}{l}\text { Azure Power } \\
\text { Global Ltd, } \\
\text { Solar Energy } \\
\text { Corporation } \\
\text { of India, } \\
\text { Canadian Solar }\end{array}$} & \multirow[t]{3}{*}{$\begin{array}{c}2015- \\
2016\end{array}$} & $\begin{array}{l}\text { Pre-invest- } \\
\text { ment }\end{array}$ & 2015 & 1 & Maximum \\
\hline & & & & Investment & $\begin{array}{l}2015- \\
2016\end{array}$ & 1 & Maximum \\
\hline & & & & $\begin{array}{l}\text { Post-invest- } \\
\text { ment }\end{array}$ & $\begin{array}{l}\text { From } \\
2016\end{array}$ & 1 & Maximum \\
\hline & \multirow{3}{*}{$\begin{array}{l}\text { Solar gen- } \\
\text { eration facil- } \\
\text { ity in Australia } \\
\quad(5 \mathrm{~mW})\end{array}$} & \multirow[t]{3}{*}{$\begin{array}{l}\text { Canadian Solar } \\
\text { Inc. }\end{array}$} & \multirow[t]{3}{*}{$\begin{array}{c}2015- \\
2016\end{array}$} & $\begin{array}{l}\text { Pre-invest- } \\
\text { ment }\end{array}$ & 2015 & 0 & Minimal \\
\hline & & & & Investment & $\begin{array}{c}2015- \\
2016\end{array}$ & 0 & Minimal \\
\hline & & & & $\begin{array}{c}\text { Post- } \\
\text { investment }\end{array}$ & $\begin{array}{l}\text { From } \\
2016\end{array}$ & 0 & Minimal \\
\hline & \multirow{3}{*}{$\begin{array}{c}\text { Solar } \\
\text { generation } \\
\text { facility in India } \\
(648 \mathrm{~mW})\end{array}$} & \multirow[t]{3}{*}{ Adani Group } & \multirow[t]{3}{*}{$\begin{array}{c}2015- \\
2016\end{array}$} & $\begin{array}{l}\text { Pre-invest- } \\
\text { ment }\end{array}$ & 2015 & 0 & Minimal \\
\hline & & & & Investment & $\begin{array}{c}2015- \\
2016\end{array}$ & 0 & Minimal \\
\hline & & & & $\begin{array}{c}\text { Post- } \\
\text { investment }\end{array}$ & $\begin{array}{l}\text { From } \\
2016\end{array}$ & 0 & Minimal \\
\hline & \multirow{3}{*}{$\begin{array}{l}\text { Solar genera- } \\
\text { tion facility in } \\
\text { Japan }(1.3 \mathrm{~mW})\end{array}$} & \multirow[t]{3}{*}{$\begin{array}{l}\text { SoftBank } \\
\text { Energy }\end{array}$} & \multirow[t]{3}{*}{$\begin{array}{c}2015- \\
2016\end{array}$} & $\begin{array}{l}\text { Pre-invest- } \\
\text { ment }\end{array}$ & 2015 & 0 & Minimal \\
\hline & & & & Investment & $\begin{array}{c}2015- \\
2016\end{array}$ & 0 & Minimal \\
\hline & & & & $\begin{array}{c}\text { Post- } \\
\text { investment }\end{array}$ & $\begin{array}{l}\text { From } \\
2016\end{array}$ & 0 & Minimal \\
\hline & \multirow[t]{3}{*}{$\begin{array}{c}\text { SPP Starom- } \\
\text { aryevskaya }\end{array}$} & \multirow{3}{*}{$\begin{array}{l}\text { Private compa- } \\
\text { ny LTD 'Solar } \\
\text { Systems' }\end{array}$} & \multirow[t]{3}{*}{$\begin{array}{c}2014- \\
2018\end{array}$} & $\begin{array}{l}\text { Pre-invest- } \\
\text { ment }\end{array}$ & 2014 & 0 & Minimal \\
\hline & & & & Investment & $\begin{array}{c}2014- \\
2018\end{array}$ & 0.599 & Average \\
\hline & & & & $\begin{array}{c}\text { Post- } \\
\text { investment }\end{array}$ & $\begin{array}{l}\text { From } \\
2018\end{array}$ & 1 & Maximum \\
\hline \multirow{3}{*}{$\begin{array}{l}\text { Hydro- } \\
\text { power }\end{array}$} & \multirow{3}{*}{$\begin{array}{l}\text { Hydropower fa- } \\
\text { cility in Canada } \\
(40.6 \mathrm{~mW})\end{array}$} & \multirow{3}{*}{$\begin{array}{c}\text { Innergex } \\
\text { Renewable En- } \\
\text { ergy Inc Pref }\end{array}$} & \multirow[t]{3}{*}{$\begin{array}{c}2015- \\
2016\end{array}$} & $\begin{array}{l}\text { Pre-invest- } \\
\text { ment }\end{array}$ & 2015 & 0.945 & Maximum \\
\hline & & & & Investment & $\begin{array}{c}2015- \\
2016\end{array}$ & 0.941 & Maximum \\
\hline & & & & $\begin{array}{c}\text { Post- } \\
\text { investment }\end{array}$ & $\begin{array}{l}\text { From } \\
2016\end{array}$ & 0.936 & Maximum \\
\hline
\end{tabular}




\begin{tabular}{|c|c|c|c|c|c|c|c|}
\hline & $\begin{array}{l}\text { Hydropower } \\
\text { plant (HPP) in }\end{array}$ & $\begin{array}{c}\text { Enel Green } \\
\text { Power, Emgesa }\end{array}$ & $\begin{array}{c}2014- \\
2015\end{array}$ & $\begin{array}{l}\text { Pre-invest- } \\
\text { ment }\end{array}$ & 2014 & 0 & Minimal \\
\hline & $\begin{array}{c}\text { Columbia (400 } \\
\mathrm{mW})\end{array}$ & & & Investment & $\begin{array}{c}2014- \\
2015\end{array}$ & 0.115 & Minimal \\
\hline & & & & $\begin{array}{c}\text { Post- } \\
\text { investment }\end{array}$ & $\begin{array}{l}\text { From } \\
2015\end{array}$ & 0.229 & Low \\
\hline & $\begin{array}{l}\text { Dam and HPP } \\
\text { in Canada }\end{array}$ & Acciona & $\begin{array}{l}2015- \\
2024\end{array}$ & $\begin{array}{l}\text { Pre-invest- } \\
\text { ment }\end{array}$ & 2015 & 0 & Minimal \\
\hline \multirow{8}{*}{$\begin{array}{l}\text { Wind } \\
\text { power }\end{array}$} & & & & Investment & $\begin{array}{c}2015- \\
2024 \\
\text { (avg. } \\
2015- \\
2018 \text { ) }\end{array}$ & 0 & Minimal \\
\hline & & & & $\begin{array}{c}\text { Post- } \\
\text { investment }\end{array}$ & $\begin{array}{l}\text { From } \\
2024\end{array}$ & \multicolumn{2}{|c|}{$\begin{array}{l}\text { No data to } \\
\text { calculate }\end{array}$} \\
\hline & $\begin{array}{l}\text { Wind genera- } \\
\text { tion facility in }\end{array}$ & Terna energy & $\begin{array}{c}2015- \\
2016\end{array}$ & $\begin{array}{l}\text { Pre-invest- } \\
\text { ment }\end{array}$ & 2015 & 0.237 & Low \\
\hline & $\begin{array}{c}\text { Greece }(10.8 \\
\mathrm{mW})\end{array}$ & & & Investment & $\begin{array}{c}2015- \\
2016\end{array}$ & 0.127 & Minimal \\
\hline & & & & $\begin{array}{c}\text { Post- } \\
\text { investment }\end{array}$ & $\begin{array}{l}\text { From } \\
2016\end{array}$ & 0.016 & Minimal \\
\hline & \multirow{3}{*}{\multicolumn{2}{|c|}{ Average values of risk }} & & $\begin{array}{l}\text { Pre-invest- } \\
\text { ment }\end{array}$ & & 0.266 & Low \\
\hline & & & & Investment & & 0.352 & Low \\
\hline & & & & $\begin{array}{c}\text { Post- } \\
\text { investment }\end{array}$ & & 0.465 & High \\
\hline
\end{tabular}

Table 4: Distribution of risks: subsidies.

\begin{tabular}{|c|c|c|c|c|c|c|c|}
\hline $\begin{array}{l}\text { RES } \\
\text { types }\end{array}$ & Project & Initiator & Period & Stage & $\begin{array}{l}\text { Dura- } \\
\text { tion }\end{array}$ & $\begin{array}{l}\text { Risk } \\
\text { (avg.) }\end{array}$ & $\begin{array}{c}\text { Risk } \\
\text { profile }\end{array}$ \\
\hline \multirow{6}{*}{$\begin{array}{l}\overline{0} \\
\overline{0} \\
0 \\
\dot{0} \\
\dot{0} \\
\dot{n}\end{array}$} & \multirow{3}{*}{$\begin{array}{l}\text { Solar power } \\
\text { plant (SPP) } \\
\text { in Germany }\end{array}$} & \multirow{3}{*}{$\begin{array}{c}\text { 7C Solarparken } \\
\text { AG, Siemens, } \\
\text { Government of } \\
\text { Bavaria }\end{array}$} & \multirow{3}{*}{$\begin{array}{l}2016- \\
2017\end{array}$} & Pre-investment & 2016 & 0 & Minimal \\
\hline & & & & Investment & $\begin{array}{c}2016- \\
2017\end{array}$ & 0 & Minimal \\
\hline & & & & $\begin{array}{l}\text { Post- } \\
\text { investment }\end{array}$ & $\begin{array}{l}\text { From } \\
2017\end{array}$ & 0 & Minimal \\
\hline & \multirow{3}{*}{$\begin{array}{c}\text { Solar gener- } \\
\text { ation facility } \\
\text { in Canada } \\
(5.64 \mathrm{~mW})\end{array}$} & \multirow[t]{3}{*}{ UGE Ltd } & \multirow{3}{*}{$\begin{array}{c}2014- \\
2016\end{array}$} & Pre-investment & 2014 & 1 & Maximum \\
\hline & & & & Investment & $\begin{array}{c}2014- \\
2016\end{array}$ & 1 & Maximum \\
\hline & & & & $\begin{array}{c}\text { Post- } \\
\text { investment }\end{array}$ & $\begin{array}{l}\text { From } \\
2016\end{array}$ & 1 & Maximum \\
\hline
\end{tabular}




\begin{tabular}{|c|c|c|c|c|c|c|c|}
\hline & \multirow{3}{*}{$\begin{array}{l}\text { Photovol- } \\
\text { taic SPP } \\
\text { in China } \\
(100 \mathrm{~mW})\end{array}$} & \multirow{3}{*}{$\begin{array}{c}\text { Panda Green } \\
\text { Energy }\end{array}$} & \multirow{3}{*}{$\begin{array}{c}2016- \\
2017\end{array}$} & Pre-investment & 2016 & 0.891 & Maximum \\
\hline & & & & Investment & $\begin{array}{c}2016- \\
2017\end{array}$ & 0.944 & Maximum \\
\hline & & & & $\begin{array}{c}\text { Post- } \\
\text { investment }\end{array}$ & $\begin{array}{l}\text { From } \\
2017\end{array}$ & 0.997 & Maximum \\
\hline & \multirow{3}{*}{$\begin{array}{c}\text { SPP in } \\
\text { China (10 } \\
\text { mW) }\end{array}$} & \multirow{3}{*}{$\begin{array}{l}\text { Zhonghuan } \\
\text { Photovoltaic } \\
\text { System Co. }\end{array}$} & \multirow{3}{*}{$\begin{array}{c}2014- \\
2015\end{array}$} & Pre-investment & 2014 & 0 & Minimal \\
\hline & & & & Investment & $\begin{array}{c}2014- \\
2015\end{array}$ & 0 & Minimal \\
\hline \multirow{13}{*}{$\begin{array}{l}\overline{0} \\
\overline{0} \\
\overline{0} \\
\overline{0} \\
\bar{z}\end{array}$} & & & & $\begin{array}{c}\text { Post- } \\
\text { investment }\end{array}$ & $\begin{array}{l}\text { From } \\
2015\end{array}$ & 0 & Minimal \\
\hline & \multirow{3}{*}{$\begin{array}{c}\text { Solar gener- } \\
\text { ation facility } \\
\text { in Canada } \\
(51 \mathrm{~mW})\end{array}$} & \multirow[t]{3}{*}{ Canadian Solar } & \multirow{3}{*}{$\begin{array}{c}2014- \\
2016\end{array}$} & Pre-investment & 2014 & 0 & Minimal \\
\hline & & & & Investment & $\begin{array}{c}2014- \\
2016\end{array}$ & 0 & Minimal \\
\hline & & & & $\begin{array}{c}\text { Post- } \\
\text { investment }\end{array}$ & $\begin{array}{l}\text { From } \\
2016\end{array}$ & 0 & Minimal \\
\hline & \multirow{3}{*}{$\begin{array}{l}\text { Wind gener- } \\
\text { ation facility } \\
\text { in Sweden } \\
(23 \mathrm{~mW})\end{array}$} & \multirow[t]{3}{*}{ Eolus Vind AB } & \multirow{3}{*}{$\begin{array}{l}2015- \\
2016\end{array}$} & Pre-investment & 2015 & 0 & Minimal \\
\hline & & & & Investment & $\begin{array}{c}2015- \\
2016\end{array}$ & 0.5 & Average \\
\hline & & & & $\begin{array}{c}\text { Post- } \\
\text { investment }\end{array}$ & $\begin{array}{c}\text { From } \\
2016\end{array}$ & 1 & Maximum \\
\hline & \multirow{3}{*}{$\begin{array}{l}\text { Wind-diesel } \\
\text { complex } \\
\text { at oil field } \\
\text { (Tatarstan) }\end{array}$} & \multirow{3}{*}{$\begin{array}{l}\text { Private com- } \\
\text { pany LTD } \\
\text { 'Aktiviti' }\end{array}$} & \multirow{3}{*}{$\begin{array}{c}2013- \\
2014\end{array}$} & Pre-investment & 2013 & 1 & Maximum \\
\hline & & & & Investment & $\begin{array}{c}2013- \\
2014\end{array}$ & 0.5 & Average \\
\hline & & & & $\begin{array}{c}\text { Post- } \\
\text { investment }\end{array}$ & $\begin{array}{l}\text { From } \\
2014\end{array}$ & 0 & Minimal \\
\hline & \multirow{3}{*}{\multicolumn{2}{|c|}{ Average values of risk }} & & Pre-investment & & 0.413 & Average \\
\hline & & & & Investment & & 0.420 & Average \\
\hline & & & & $\begin{array}{c}\text { Post- } \\
\text { investment }\end{array}$ & & 0.428 & Average \\
\hline
\end{tabular}

Table 5: Distribution of risks: absence of state support.

\begin{tabular}{|c|c|c|c|c|c|c|c|}
\hline $\begin{array}{l}\text { RES } \\
\text { types }\end{array}$ & Project & Initiator & Period & Stage & Duration & $\begin{array}{c}\text { Risk } \\
\text { (avg.) }\end{array}$ & $\begin{array}{c}\text { Risk } \\
\text { profile }\end{array}$ \\
\hline \multirow{3}{*}{$\begin{array}{l}\overline{0} \\
0 \\
0 \\
\bar{a} \\
\overline{0} \\
\dot{0}\end{array}$} & \multirow{3}{*}{$\begin{array}{l}\text { Solar genera- } \\
\text { tion facility in } \\
\text { Alamida dis- } \\
\text { trict, USA }\end{array}$} & \multirow{3}{*}{$\begin{array}{c}\text { NextEra } \\
\text { Energy, } \\
\text { Google, GE }\end{array}$} & \multirow[t]{3}{*}{$\begin{array}{c}2014- \\
2015\end{array}$} & $\begin{array}{c}\text { Pre- } \\
\text { investment }\end{array}$ & 2014 & 0 & Minimal \\
\hline & & & & Investment & $\begin{array}{c}2014- \\
2015\end{array}$ & 0 & Minimal \\
\hline & & & & $\begin{array}{c}\text { Post- } \\
\text { investment }\end{array}$ & $\begin{array}{l}\text { From } \\
2015\end{array}$ & 0 & Minimal \\
\hline
\end{tabular}




\begin{tabular}{|c|c|c|c|c|c|c|c|}
\hline & \multirow{3}{*}{$\begin{array}{l}\text { Photovoltaic } \\
\text { power plant in } \\
\text { El Salvador } \\
(101 \mathrm{~mW})\end{array}$} & \multirow{3}{*}{$\begin{array}{c}\text { NEOEN, } \\
\text { Del Sur, } \\
\text { Inter- } \\
\text { American } \\
\text { Investment } \\
\text { Corporation }\end{array}$} & \multirow[t]{3}{*}{$\begin{array}{c}2015- \\
2017\end{array}$} & $\begin{array}{c}\text { Pre- } \\
\text { investment }\end{array}$ & 2015 & 1 & Maximum \\
\hline & & & & Investment & $\begin{array}{l}2015- \\
2017\end{array}$ & 0.994 & Maximum \\
\hline & & & & $\begin{array}{c}\text { Post- } \\
\text { investment }\end{array}$ & $\begin{array}{l}\text { From } \\
2017\end{array}$ & 0.987 & Maximum \\
\hline & \multirow{3}{*}{$\begin{array}{l}\text { SPP in North } \\
\text { Carolina, USA } \\
(32.1 \mathrm{~mW})\end{array}$} & \multirow{3}{*}{$\begin{array}{l}\text { Phoenix } \\
\text { Solar AG, } \\
\text { Duke En- } \\
\text { ergy }\end{array}$} & \multirow{3}{*}{$\begin{array}{l}2012- \\
2015\end{array}$} & Pre- & 2012 & 0 & Minimal \\
\hline & & & & $\begin{array}{l}\text { investment } \\
\text { Investment }\end{array}$ & $\begin{array}{l}2012- \\
2015\end{array}$ & 0.111 & Minimal \\
\hline & & & & $\begin{array}{c}\text { Post- } \\
\text { investment }\end{array}$ & $\begin{array}{l}\text { From } \\
2015\end{array}$ & 0.222 & Low \\
\hline & \multirow{3}{*}{$\begin{array}{l}\text { Solar genera- } \\
\text { tion facility in } \\
\text { New-York, } \\
\text { USA (15.3 } \\
\text { mW) }\end{array}$} & \multirow[t]{3}{*}{ UGE Ltd } & \multirow[t]{3}{*}{$\begin{array}{l}2016- \\
2017\end{array}$} & $\begin{array}{c}\text { Pre- } \\
\text { investment }\end{array}$ & 2016 & 1 & Maximum \\
\hline & & & & Investment & $\begin{array}{l}2016- \\
2017\end{array}$ & 0.5 & Average \\
\hline & & & & $\begin{array}{c}\text { Post- } \\
\text { investment }\end{array}$ & $\begin{array}{l}\text { From } \\
2017\end{array}$ & 0 & Minimal \\
\hline & \multirow{3}{*}{$\begin{array}{l}\text { Solar thermal } \\
\text { PP }(280 \mathrm{MW}) \text {, } \\
\text { Arizona, USA }\end{array}$} & \multirow[t]{3}{*}{$\begin{array}{c}\text { Government } \\
\text { of Arizona }\end{array}$} & \multirow[t]{3}{*}{$\begin{array}{c}2010- \\
2016\end{array}$} & $\begin{array}{c}\text { Pre- } \\
\text { investment }\end{array}$ & 2010 & 0 & Minimal \\
\hline & & & & Investment & $\begin{array}{l}2010- \\
2016\end{array}$ & 0.5 & Average \\
\hline & & & & $\begin{array}{c}\text { Post- } \\
\text { investment }\end{array}$ & $\begin{array}{l}\text { From } \\
2016\end{array}$ & 1 & Maximum \\
\hline \multirow{6}{*}{ 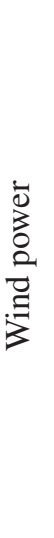 } & \multirow{3}{*}{$\begin{array}{l}\text { Wind genera- } \\
\text { tion facility in } \\
\text { North sea ( } 312 \\
\mathrm{~mW})\end{array}$} & \multirow{3}{*}{$\begin{array}{l}\text { Dong En- } \\
\text { ergy, PNE } \\
\text { Wind }\end{array}$} & \multirow[t]{3}{*}{$\begin{array}{l}2014- \\
2015\end{array}$} & $\begin{array}{c}\text { Pre- } \\
\text { investment }\end{array}$ & 2014 & 0 & Minimal \\
\hline & & & & Investment & $\begin{array}{l}2014- \\
2015\end{array}$ & 0 & Minimal \\
\hline & & & & $\begin{array}{c}\text { Post- } \\
\text { investment }\end{array}$ & $\begin{array}{l}\text { From } \\
2015\end{array}$ & 0 & Minimal \\
\hline & \multirow{3}{*}{$\begin{array}{l}\text { Coastal wind } \\
\text { power plant } \\
\text { (WPP) in North } \\
\text { sea, Belgium } \\
(165 \mathrm{~mW})\end{array}$} & \multirow{3}{*}{$\begin{array}{c}\text { Sumitomo } \\
\text { Corporation, } \\
\text { Parkwind } \\
\text { NV, Mee- } \\
\text { wind }\end{array}$} & \multirow[t]{3}{*}{$\begin{array}{l}2015- \\
2017\end{array}$} & $\begin{array}{c}\text { Pre- } \\
\text { investment }\end{array}$ & 2015 & 0 & Minimal \\
\hline & & & & Investment & $\begin{array}{l}2015- \\
2017\end{array}$ & 0 & Minimal \\
\hline & & & & $\begin{array}{c}\text { Post- } \\
\text { investment }\end{array}$ & $\begin{array}{l}\text { From } \\
2017\end{array}$ & 0 & Minimal \\
\hline \multirow{3}{*}{ 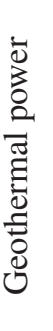 } & \multirow{3}{*}{$\begin{array}{c}\text { Geothermal } \\
\text { power plant } \\
(\mathrm{GPP}) \text { in Philip- } \\
\text { pines }(20 \mathrm{~mW})\end{array}$} & $\begin{array}{l}\text { PetroGreen } \\
\text { Energy, }\end{array}$ & \multirow[t]{3}{*}{2014} & $\begin{array}{c}\text { Pre- } \\
\text { investment }\end{array}$ & 2014 & 0.994 & Maximum \\
\hline & & TranAsia Oil & & Investment & 2014 & 0.994 & Maximum \\
\hline & & $\begin{array}{c}\text { \& Energy } \\
\text { Develop- } \\
\text { ment, PNOC } \\
\text { Renewables } \\
\text { Corp. } \\
\end{array}$ & & $\begin{array}{c}\text { Post- } \\
\text { investment }\end{array}$ & $\begin{array}{l}\text { From } \\
2014\end{array}$ & 0.994 & Maximum \\
\hline
\end{tabular}




\begin{tabular}{|c|c|c|c|c|c|c|c|}
\hline \multirow{5}{*}{ 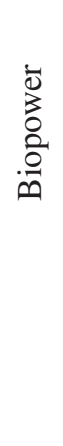 } & $\begin{array}{l}\text { Conversion } \\
\text { of CHP to a }\end{array}$ & $\begin{array}{l}\text { Dong } \\
\text { Energy, }\end{array}$ & $\begin{array}{l}2016- \\
2017\end{array}$ & $\begin{array}{c}\text { Pre- } \\
\text { investment }\end{array}$ & 2016 & 0 & Minimal \\
\hline & $\begin{array}{c}\text { biomass plant, } \\
\text { Denmark }\end{array}$ & $\begin{array}{c}\text { AffaldVarme } \\
\text { Aarhus }\end{array}$ & & Investment & $\begin{array}{l}2016- \\
2017\end{array}$ & 0 & Minimal \\
\hline & & & & $\begin{array}{c}\text { Post- } \\
\text { investment }\end{array}$ & $\begin{array}{l}\text { From } \\
2017\end{array}$ & 0 & Minimal \\
\hline & $\begin{array}{l}\text { Tidal marine } \\
\text { power plant, }\end{array}$ & $\begin{array}{c}\text { Atlantis } \\
\text { Resources }\end{array}$ & $\begin{array}{l}2016- \\
2017\end{array}$ & $\begin{array}{c}\text { Pre- } \\
\text { investment }\end{array}$ & 2016 & 1 & Maximum \\
\hline & UK (160 mW) & $\begin{array}{l}\text { Ltd, Natiral } \\
\text { Energy Wire }\end{array}$ & & Investment & $\begin{array}{l}2016- \\
2017\end{array}$ & 1 & Maximum \\
\hline \multirow{7}{*}{ 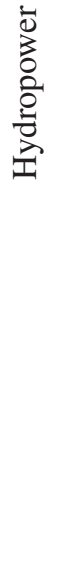 } & & & & $\begin{array}{c}\text { Post- } \\
\text { investment }\end{array}$ & $\begin{array}{l}\text { From } \\
2017\end{array}$ & 1 & Maximum \\
\hline & $\begin{array}{l}\text { HPP Boguchan- } \\
\text { skaya }\end{array}$ & $\begin{array}{l}\text { Private } \\
\text { company }\end{array}$ & $\begin{array}{l}2012- \\
2015\end{array}$ & $\begin{array}{c}\text { Pre- } \\
\text { investment }\end{array}$ & 2012 & 0 & Minimal \\
\hline & & $\begin{array}{l}\text { LTD 'Sibir } \\
\text { Engineering' }\end{array}$ & & Investment & $\begin{array}{l}2012- \\
2015\end{array}$ & 0 & Minimal \\
\hline & & & & $\begin{array}{c}\text { Post- } \\
\text { investment }\end{array}$ & $\begin{array}{l}\text { From } \\
2015\end{array}$ & 0 & Minimal \\
\hline & & & & $\begin{array}{c}\text { Pre- } \\
\text { investment }\end{array}$ & & 0.363 & Low \\
\hline & Average val & ues of risk & & Investment & & 0.373 & Low \\
\hline & & & & $\begin{array}{c}\text { Post- } \\
\text { investment }\end{array}$ & & 0.382 & Low \\
\hline
\end{tabular}

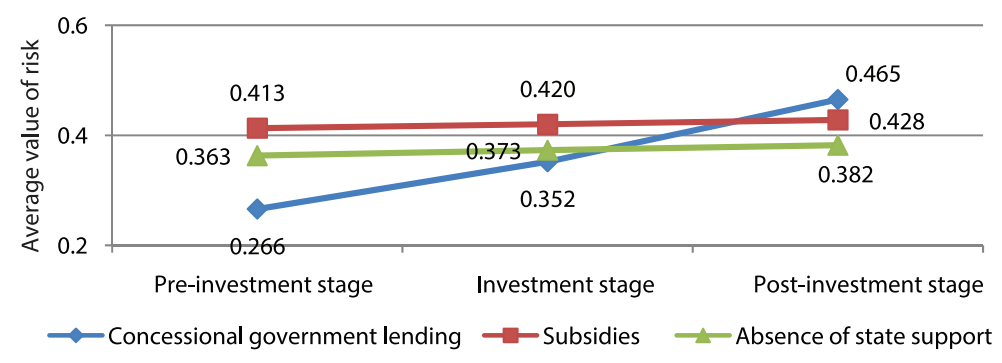

Figure 1: Distribution of the average level of risks in RE projects: by type of state support.

Table 6: Average risk in the case of exclusion of projects with zero risk.

\begin{tabular}{lcccccc}
\hline & \multicolumn{5}{c}{ Average values of risk by project stages } \\
\cline { 2 - 7 } $\begin{array}{l}\text { Instruments } \\
\text { of state } \\
\text { support }\end{array}$ & \multicolumn{2}{c}{ Pre-investment } & \multicolumn{2}{c}{ Investment } & \multicolumn{2}{c}{ Post-investment } \\
& $\begin{array}{c}\text { Original } \\
\text { sample }\end{array}$ & $\begin{array}{c}\text { Excluding } \\
\text { 'zero-risk' } \\
\text { projects }\end{array}$ & $\begin{array}{c}\text { Original } \\
\text { sample }\end{array}$ & $\begin{array}{c}\text { Excluding } \\
\text { 'zero-risk' } \\
\text { projects }\end{array}$ & $\begin{array}{c}\text { Original } \\
\text { sample }\end{array}$ & $\begin{array}{c}\text { Excluding } \\
\text { 'zero-risk' } \\
\text { projects }\end{array}$ \\
\hline $\begin{array}{l}\text { Government } \\
\text { lending }\end{array}$ & 0.266 & 0.665 & 0.352 & 0.702 & 0.465 & 0.738 \\
Subsidies & 0.413 & 0.963 & 0.420 & 0.815 & 0.428 & 0.666 \\
\hline
\end{tabular}


a)

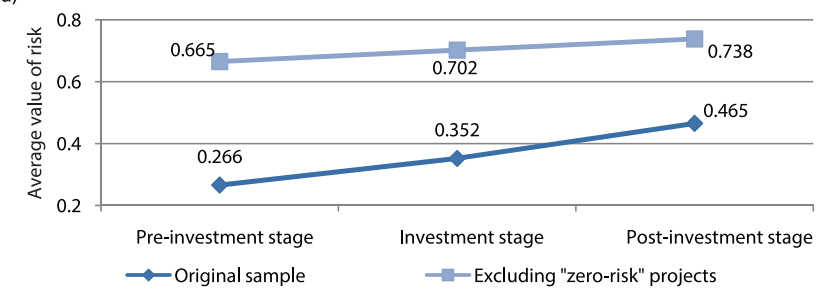

b)

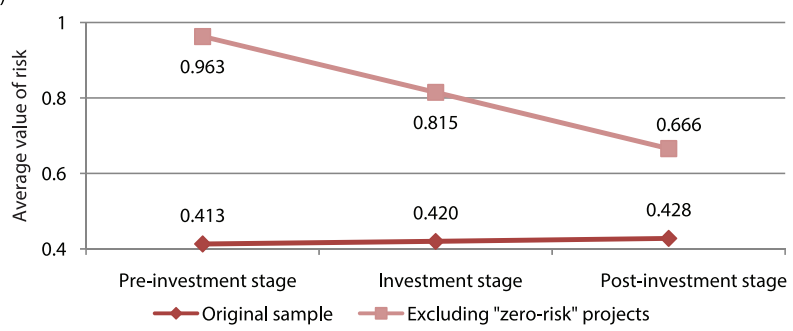

Figure 2: Comparison of average risk in the case of exclusion of projects with zero risk, by: (a) government lending, (b) subsidies.

The average risk in such RE projects (last line of Table 5 and Fig. 1) is consistently in the group of low risk.

One of the criteria for the ineffectiveness of state stimulation of the sector is the provision of support to those RE projects, which are initially characterized by a minimal value of risk. The author assumes that such projects do not need any incentives at stage one. For the subsequent assessment, the average risk values were calculated and a comparative analysis was performed for the cases of government lending and subsidies without taking into account the described RE projects (Table 6 and Fig. 2).

Calculations show that in the case of concessional government lending, the real level of risk almost doubles and ends up in the group of high risk. The exclusion of zero-risk projects from the group of subsidy recipients revealed an interesting dynamic. At the pre-investment stage, the average risk tends to the maximum, and by the end of the project is reduced to a high level. In practice, this means that, on the one hand, a tool of non-repayable subsidies can be effective for RE projects, which are characterized by initially significant level of risk. On the other hand, it provoked an increase of risk in risk-free projects at the pre-investment stage. However, in the case of subsidies, the average risk has also almost doubled.

\section{CONCLUSIONS}

A rapid pace of RE development has been achieved through active state support for this sector. However, the research presented in the article clarifies this view. Calculations showed that the most effective incentive tool is in fact the absence of state support mechanisms for the sector. In this case, there are no sharp changes in risk, and its average value is within the low level. Provision of subsidies for RE, in general, also shows a stable value of risk. However, in comparison with the absence of support, the level of risk increases to a medium value. The least effective tool was concessional government lending. When this mechanism was applied, risk at the pre-investment stage was the lowest (low risk group), and by the post-investment period it showed the highest possible value among all projects. Among the reasons for such results is the high impact of political and legislative risks [18]-[20]. 
The obtained results allow determining promising methodological directions for further research. They are associated with the development of new deterministic risk assessment tools for the main stages of the project, taking into account the specific character of RE. The new mechanism should help to answer a difficult question as to what tools of state support are best suitable for which projects, and which projects do not require additional incentives at all, taking into account the regional affiliation and size of RE facilities. [21]-[23]

\section{ACKNOWLEDGMENTS}

The work was supported with a grant of the Russian Science Foundation (project № 17-7810039) (chapters 1-4) and by Act 211 of the Government of the Russian Federation, contract № 02.A03.21.0006 (chapter 4).

\section{REFERENCES}

[1] Ermolenko, G.V., Tolmacheva, I.S., Ryapin I.Y., Fetisova Y.A., Matshura A.A. \& Reutiva A.B., Handbook on Renewable Energy the European Union, Institute of Energy SRU GSE: Moscow, p. 96, 2016.

[2] Dia-Core project, The Impact of Risks in Renewable Energy Investment and the Role of Smart Policies, available at http://diacore.eu/results/item/enhancing-res-investmentsfinal-report (accessed 01 April 2019).

[3] Panepinto, D., Gitelman, L., Kozhevnikov, M., Magaril, E., Magaril, R. \& Zanetti, M.C., Energy from biomass for sustainable cities. IOP Conference Series: Earth and Environmental Science, 72(1), 2017. https://doi.org/10.1088/1755-1315/72/1/012021

[4] Chebotareva, G., Leading factors of market profitability of the renewable energy companies. Proceedings of the 2 nd International Conference on Social, Economic and Academic Leadership, Vol. 217, pp. 277-287, 2018. https://doi.org/10.2991/icseal-18.2018.39

[5] International Renewable Energy Agency (IRENA), Renewable Energy Statistics 2017. http://www.irena.org/DocumentDownloads/Publications/IRENA_Renewable_Energy_ Statistics_2017.pdf (accessed 10 January 2019).

[6] International Renewable Energy Agency (IRENA), Renewable energy highlights. http:// www.irena.org/DocumentDownloads/Publications/IRENA_Renewable_energy_highlights_July_2017.pdf (accessed 10 Febraury 2019).

[7] Renewable Energy Policy Network for the 21st Century (REN21), State of renewable energy 2016. Global report, http://www.ren21.net/wp-content/uploads/2016/10/ REN21_GSR2016_KeyFindings_RUSSIAN.pdf (accessed 11 February 2019).

[8] Renewable Energy Policy Network for the 21st Century (REN21), State of renewable energy 2017.Globalreport.http://www.ren21.net/wp-content/uploads/2017/10/17-8399_ GSR_2017_KEY-FINDINGS_RU_low.pdf (accessed 20 March 2019).

[9] Renewables 2018, Global status report. http://www.ren21.net/gsr-2018 (accessed 20 March 2019).

[10] Frankfurt School-UNEP Centre/BNEF 2018, Global Trends in Renewable Energy Investment 2018. http://www.greengrowthknowledge.org/sites/default/files/downloads/resource/Global_Trends_in_Renewable_Energy_Investment_Report_2018.pdf (accessed 20 March 2019).

[11] Chebotareva, G., Risk-oriented approach to competition assessment in the global renewable energy sources market. WIT Transactions on The Built Environment, 179, pp. 345-355, 2018. https://doi.org/10.2495/ug180321 
[12] Mokhov, V.G., Chebotareva, G.S. \& Khomenko, P.M., Modelling of 'green' investments risks. Vestnik Yuzhno-Ural'skogo gosudarstvennogo universiteta. Seriya 'Matematicheskoe modelirovanie i programmirovanie', 11(2), pp. 154-159, 2018. https://doi.org/10.14529/mmp180213

[13] Sorland B.F. \& Rudel M.G.N., What drives Financial Distress Risk and Default Rates of Leveraged Buyout Targets? Empirical Evidence from European Transactions, Norwegian School of Economics: Norway, 2015.

[14] Khaidarshina G.A., Integrated model to assess the risk of bankruptcy. Finance, 2, pp. 67-69, 2009.

[15] Lombardi, P. \& Schwabe, F., Sharing economy as a new business model for energy storage systems. Applied Energy, 188, pp. 485-496, 2017. https://doi.org/10.1016/j. apenergy.2016.12.016

[16] Ascione, F., Bianco, N., De Stasio, C., Mauro, G.M. \& Vanoli, G.P., Multi-stage and multi-objective optimization for energy retrofitting a developed hospital reference building: a new approach to assess cost-optimality. Applied Energy, 174, pp. 37-68, 2016. https://doi.org/10.1016/j.apenergy.2016.04.078

[17] Johnston, S., Nonrefundable tax credits versus grants: The impact of subsidy form on the effectiveness of subsidies for renewable energy. Journal of the Association of Environmental and Resource Economists, 6(3), pp. 433-460, 2019. https://doi. org/10.1086/702736

[18] Gonzalez, A., Riba, J.R., Esteban, B. \& Rius, A., Environmental and cost optimal design of a biomass-Wind-PV electricity generation system. Renewable Energy, 126, pp. 420-430, 2018. https://doi.org/10.1016/j.renene.2018.03.062[AQ2]

[19] Bhattacharya, M., Paramati, S.R., Ozturk, I. \& Bhattacharya, S., The effect of renewable energy consumption on economic growth: evidence from top 38 countries. Applied Energy, 162, pp. 733-741, 2016. https://doi.org/10.1016/j.apenergy.2015.10.104

[20] Rediske, G., Siluk, J.C.M., Gastaldo, N.G., Rigo, P.D. \& Rosa, C.B., Determinant factors in site selection for photovoltaic projects: a systematic review. International Journal of Energy Research, 43(5), pp. 1689-1701, 2019. https://doi.org/10.1002/er.4321

[21] Zhang, C. \& Yang, J., Economic benefits assessments of 'coal-to-electricity' project in rural residents heating based on life cycle cost. Journal of Cleaner Production, 213, pp. 217-224, 2019. https://doi.org/10.1016/j.jclepro.2018.12.077

[22] [McInerney, C. \& Bunn, D.W., Expansion of the investor base for the energy transition. Energy Policy, 129, pp. 1240-1244, 2019. https://doi.org/10.1016/j.enpol.2019.03.035

[23] Oliveira, T., Varum, C. \& Botelho, A., Econometric modeling of $\mathrm{CO}_{2}$ emissions abatement: comparing alternative approaches. Renewable and Sustainable Energy Reviews, 105, pp. 310-322, 2019. https://doi.org/10.1016/j.rser.2019.02.001 